\title{
Mindeord for museologen Marc Maure
}

Marc Maure, norsk-fransk museolog, der igennem mange år bidrog aktivt med artikler og ideer til Nordisk Museologi, døde 13. januar 2012. Jeg nåede aldrig at møde ham ansigt til ansigt. Men siden min tiltrædelse som redaktør mailede jeg jævnligt med ham om museologiens og tidsskriftets udvikling. Begge dele var han levende engageret i. Han var en fin sparringspartner, der altid havde konstruktive råd til mig som redaktør, og igennem vores dialog oplevede jeg ham som meget betænksom. Sammen nåede Marc Maure og jeg at redigere to numre om udstillingsmediet, dets virkemidler og historie (NM nr. 1 og 2 2009). Det var hans idé at lave to temanumre. Han betragtede udstillingen som verdens ældste og mest udbredte massemedium og undrede sig over, at der ikke havde været større forskningsinteresse for udstillingens historie. I forordet til nr. 2 efterlyste han udstillingens historie i et nordisk perspektiv. Han skrev selv på en artikel om emnet, men den nåede desværre aldrig at blive færdig.

I nr. 21995 skrev han en interessant artikel om "The exhibition as theatre - on the staging of museum objects", hvor han sammenlignede udstillingens karakteristiske træk med teatrets og omtalte udstillingen som en teaterscene og museologen som en teaterinstruktør. Men i de mange museumsudstillinger, som han havde set, savnede han teatrets evne til at gøre brug af humor og menneskelige følelser som håb, længsel og fortvivlelse, og efterlyste teaterinstruktørens evner til at sætte dagsorden og at iscenesætte en handling og et budskab.

Et andet emne, som lå ham meget på sinde, var GULAG-museerne i Rusland, som han skrev en artikel om i nr. 2 2006. Det var en meget medrivende artikel, fordi han kunne forplante sine iagttagelser til læseren og formåede at give et direkte indblik i livets mere grusomme historie. Hans artikler var inspirerende at læse og forsøgte netop at forene universitetslektorens analytiske blik og museumsmenneskets formidlingsevner. Det lå ham meget på sinde at bygge bro mellem universitetsog museumskulturen eller at skabe en fælles platform, der rummede det bedste fra begge. Det lykkedes i hans egne artikler.

Nordisk Museologi vil savne hans ildhu og engagement.

Ane Hejlskov Larsen, redaktør for Nordisk Museologi 